\title{
Ecological succession of zooplankton species in a temporary river in a semi arid region of Brazil
}

\author{
Maria Cristina Crispim ${ }^{1 *}$, Ronilson José da Paz $^{2}$ and Takako \\ Watanabe ${ }^{1}$
}

${ }^{1}$ Universidade Federal da Paraíba (UFPB), Centro de Ciências Exatas e da Natureza, Departamento de Sistemática e Ecologia, CEP 58051-900, João Pessoa, PB, Brazil. *E-mail: mccrispim@hotmail.com.

${ }^{2}$ Instituto Brasileiro do Meio Ambiente e dos Recursos Naturais Renováveis (IBAMA), Caixa Postal 5063, CEP 58051-900, João Pessoa, PB, Brazil.

\begin{abstract}
In the semi arid region of Brazil, the rivers and reservoirs are temporary, existing at times, even years, without water. The animal communities have to develop special strategies to survive when the environment is dry and to multiply, when water arrives. This study analyzed the zooplankton community upon the beginning of the rainy season in a temporary river (in remaining ponds) in Northeast Brazil. Ecological succession of species was analyzed throughout 9 months during which there was water in the river. During this period, samples were collected on days 15, 28, 37 and 43 after the start of raining and monthly afterwards. From diapause 28 rotifer species and 5 subspecies; 8 cladoceran species and 8 copepod species ecloded. The first cladoceran to appear was Moina minuta, which reached high densities, 1,234 ind. $\mathrm{L}^{-1}$, followed by Ceriodaphnia comuta, observed on day 28 , and by Diaphanosoma spimilosum observed 37 days after the rain event. The first copepods to appear were Mesocyclops meridianus and Muscocyclops sp., both in the first sample (day 15). Of all the species, 21 were observed only once. Among the rotifers 10 species were observed in the first sample. This group was present in high densities e.g. Conochilus sp., with 20,403 ind. $\mathrm{L}^{-1}$, Keratella tropica with 9,392 ind. $\mathrm{L}^{-1}$ and $K$. lenzi with 1,149 ind. $\mathrm{L}^{-1}$. Species densities were correlated with chlorophyll $a$, nitrate and ammonium. New ephippia production was related with total zooplankton densities, chlorophyll-a, nitrate and ammonium.
\end{abstract}

Keywords: Ecological succession, zooplankton, temporary habitat, semi arid region.

\section{Introduction}

Ecological succession is an ordered process of community development involving alterations in the specific structure and community process, in time. These successions occur due to modifications in the physical environment occasioned by the community, culminating with a stable one (Odum, 1988). As drought is a cyclical phenomenon (Barbosa et al.,
2012), the organisms have to develop strategies of life that allow them to survive when the environment is adverse. Diapause is the strategy used by crustaceans (Fryer, 1996; Rossi et al., 1996; Crispim and Watanabe, 2001; Crispim et al., 2003) and rotifers (King and Snell, 1980; Gilbert, 1995) to survive such periods. Diapause in some studied crustacea lasted from some 
months to about 55 years (Hairston and Cáceres, 1996). The species adapted to this kind of environment, must have the ability to use the little time the habitat has water to rapidly multiply and to produce a diapause stage again. When organisms hatched from resting eggs, e.g. daphnids, they exhibited a significantly higher reproductive effort in the adult instars 1 and 2. The first clutch size was twice that compared to exephippial females (Arbaciauskas, 1998), allowing the population to rapidly attain high densities. The recruitment of zooplankton in temporary water-bodies from their resting stages is governed by a complexity of factors which regulate their production, distribution, hatchability, viability and survival during the dry periods (Chatterjee and Gopal, 1998). Hatching in arid regions is not only stimulated by the presence of water, but by a rise in temperature as well (Fryer, 1996).

Temporary rivers undergo great changes through a hydrological cycle. They go from a completely dry period to a running water period. When the rains fall, the rivers receive water, but as soon as the rain stops, most of them become shallow little ponds in some deeper places. At this time the chemical environmental conditions change, and the water becomes eutrophic and hypereutrophic until complete disappearance in some aquatic systems.

Zooplankton species only eclode when the environment is suitable, and not all at the same time. Since the special requirements are not the same for all species, it is possible to observe an ecological succession among the species along the period the river remains with water.

As these environments are strongly related with the water cycle, their hydrological fluctuations can be so large that a pond rarely remains the same from one year to the next. Wherefore it is difficult to find, clear annual patterns in zooplankton communities (Serrano and Toja, 1998). Ponce-Palafox and ArredondoFigueroa (1998) noted that the metabolism of the water column in four temporary tropical freshwater ponds depended largely on the fluctuations in water volume and on the relation between this and dissolved substances, organic matter and the quantity of phytoplankton.

This work describes the ecological succession observed on the zooplankton community, in a temporary river in northeast Brazil, during a period of 9 months.

\section{Study Site}

Taperoá River is located in the Cariri Region in Paraíba State, in Brazil. The sampling site is located near São João do Cariri town in the coordinates $07^{\circ} 43^{\prime} \mathrm{S}$ and $36^{\circ} 31^{\prime} \mathrm{W}$, at an altitude of $460 \mathrm{~m}$. Water was never enough to make the river flow so the results are related to a little pond created by the rain.

\section{Methodology}

Samples were collected from the river $15,28,37,43$ daysafter the rainfall and monthly afterwards for nearly 9 months.

\section{Zooplankton}

40 liters of water were filtered in a $50 \mu \mathrm{m}$ mesh filter and fixed in a $4 \%$ formol solution saturated with sugar. Three samples were collected on each date. Density results presented in the work are average values of the three samples. Densities were estimated by counting in a Sedgewick Rafter chamber, of at least 100 individuals for sample, and numbers were placed in the following formula:

$$
\mathrm{D}=\frac{\text { s.v. } x \mathrm{~N}}{\text { c.v. }} / \mathrm{f.v}
$$

Were $\mathrm{D}=$ densities

S.v = sample volume

$\mathrm{N}=$ species number

c. $\mathrm{v}=$ counted volume

f.v $=$ filtered volume

\section{biomass}

Chlorophyll-a and phytoplankton

Chlorophyll $a$ and phytoplankton biomass were analyzed as described by Golterman et al. (1978). 
Table 1. Chemical parameters in the Taperoá River along the study period.

\begin{tabular}{lrrrrrrrrr}
\hline Days & $\mathbf{1 5}$ & $\mathbf{4 3}$ & $\mathbf{6 9}$ & $\mathbf{9 9}$ & $\mathbf{1 4 0}$ & $\mathbf{1 7 0}$ & $\mathbf{1 9 3}$ & $\mathbf{2 1 1}$ & $\mathbf{2 5 5}$ \\
\hline alc $\left(\mu \mathrm{g} . \mathrm{L}^{-1}\right)$ & 75.0 & 146.0 & 42.0 & 98.0 & 115.0 & 125.0 & 186.0 & - & - \\
har $\left(\mu \mathrm{g} . \mathrm{L}^{-1}\right)$ & 180.0 & 240.0 & 190.0 & 220.0 & 110.0 & 298.0 & 300.0 & - & - \\
am $\left(\mu \mathrm{g} . \mathrm{L}^{-1}\right)$ & 412.0 & 133.3 & 183.4 & 322.0 & 260.8 & 54.5 & 93.3 & - & - \\
nit $\left(\mu \mathrm{g} . \mathrm{L}^{-1}\right)$ & 309.7 & 599.7 & 816.3 & 149.7 & 106.3 & 69.7 & - & - & - \\
Pt $\left(\mu \mathrm{g} . \mathrm{L}^{-1}\right)$ & 5.0 & 15.0 & 19.9 & 6.3 & 8.9 & 20.0 & - & 66.8 & 61.9 \\
\hline
\end{tabular}

alc = alkalinity; har = hardness; am = ammonium; nit = nitrate; $\mathrm{Pt}=$ phosphorus total.

\section{Chemical factors}

Alkalinity was analyzed following Golterman et al. (1978). Water hardness as described in Standard Methods (Eaton et al., 1995). Nitrate, nitrite and ammonium was determined by the colorimetric method, described by Rodier (1975), and total phosphorus was analyzed following Standard Methods (Eaton et al., 1995).

\section{Correlations}

Pearson's correlations were used in a SPSS computing Program.

\section{Results}

\section{Cladocera}

During the study period 9 species of Cladocera were found in the Taperoá River: Moina minuta, Ceriodaphnia comuta, Diaphanosoma spinulosum, Macrothrix sp., Alonella hamulata, Alona poppei, Ilyocryptus spinifer, Chydorus sphaericus, and Chydorus eurynotus. M. minuta was the first cladoceran to appear after the initiation of rainfall. This species was observed in days 15 and 28, with high densities (115.5 and 1,234.7 ind. $\left.L^{-1}\right)$, being observed with very low densities $\left(0.18\right.$ ind. $\left.\mathrm{L}^{-1}\right)$ in day 69 , and was not observed again (Figure 1). C. cornuta was the second species to appear, on day 28. It attained its highest density on day 37 (30.0 ind. $\mathrm{L}^{-1}$ ) and afterwards was only present at very low densities $(0.02$ and 0.03 ind. $\left.\mathrm{L}^{-1}\right)$ respectively on days 69 and 140. It lived together with $M$. minuta (day 28 ) and with $D$. spinulosum that was observed on day 37 . The latter species was only observed on two dates, appearing in day 69 at very low densities $\left(0.17\right.$ ind. $\left.\mathrm{L}^{-1}\right)$, A. hamulata and Macrothrix sp. were only observed on day 69 , both with very low densities. A. poppei was also observed on day 69 , but achieved its highest density on day 99 with 5.2 ind. $\mathrm{L}^{-1}$. I. spinifer appeared only on day 170 , with 0.7 ind. $L^{-1}$ and C. sphaericus on day 193 , with 0.5 ind. $\mathrm{L}^{-1}$. Thus, the sequence of cladocerans observed was as follow:

M. minuta $\rightarrow$ C. cornuta $\rightarrow$ D. spinulosum A. hamulata = Macrothrix sp. $=$ A. poppei $\rightarrow$ I. spinifer $\rightarrow$ C. sphaericus $\rightarrow$ C. eurynotus.

The species of this group were present in the water for a few days. They hatched from the sediments in isolated pools as the river did not run this year, increased their populations and then disappeared again, probably after producing diapausing stages once again. on Table 1.

Chemical parameters are described

Diversity indices in this group reached the highest value on day 69 with $\mathrm{H}^{\prime}=1.64$. On many dates this index was 0.0 due the presence of only one species (Figure 2).

The Pearson's coefficient correlation between cladocerans and chemical environmental factors was negative between $M$. minuta and alkalinity $(\mathrm{r}=-0.757, \mathrm{~N}=7, \mathrm{P}<0.05)$.

\section{Copepoda}

Among the copepods 9 taxa were found during the study period. The cyclopoids Mesocyclops meridianus, M. brasilianus, Muscocyclops sp., Metacyclops brauni, Thermocyclops crassus, and 2 species unidentified, named here as cyclopoid sp.1 and cyclopoid sp.3; the Calanoida Notodiaptomuns cearensis and one species of Harpacticoida, not identified yet. The first copepod species to 


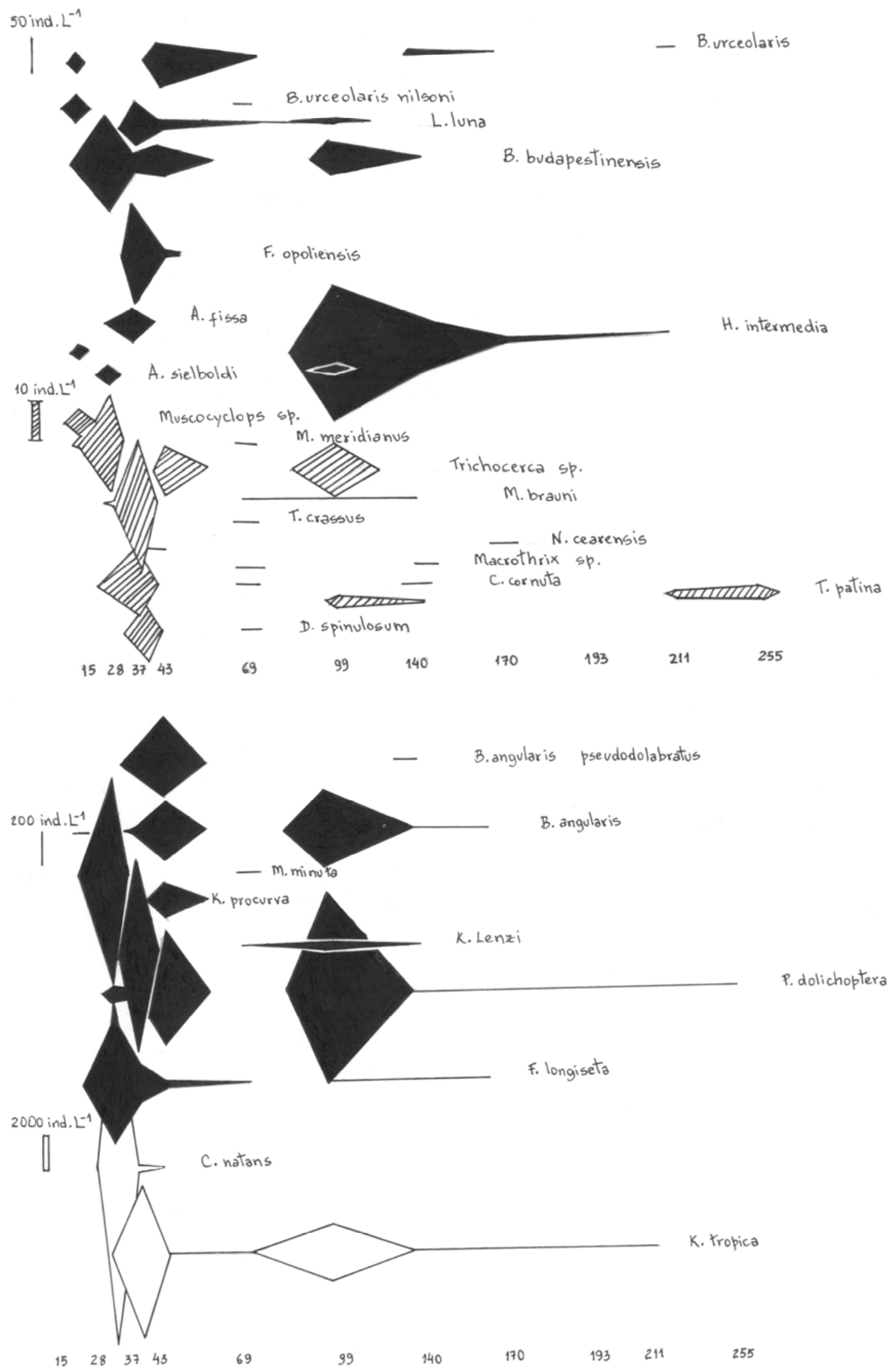

Figure 1. Densities of the more abundant species of Cladocera, Copepoda and Rotifera along the study period.

Braz. J. Biol. Sci., 2014, v. 1, n. 2, p. 51-58. 


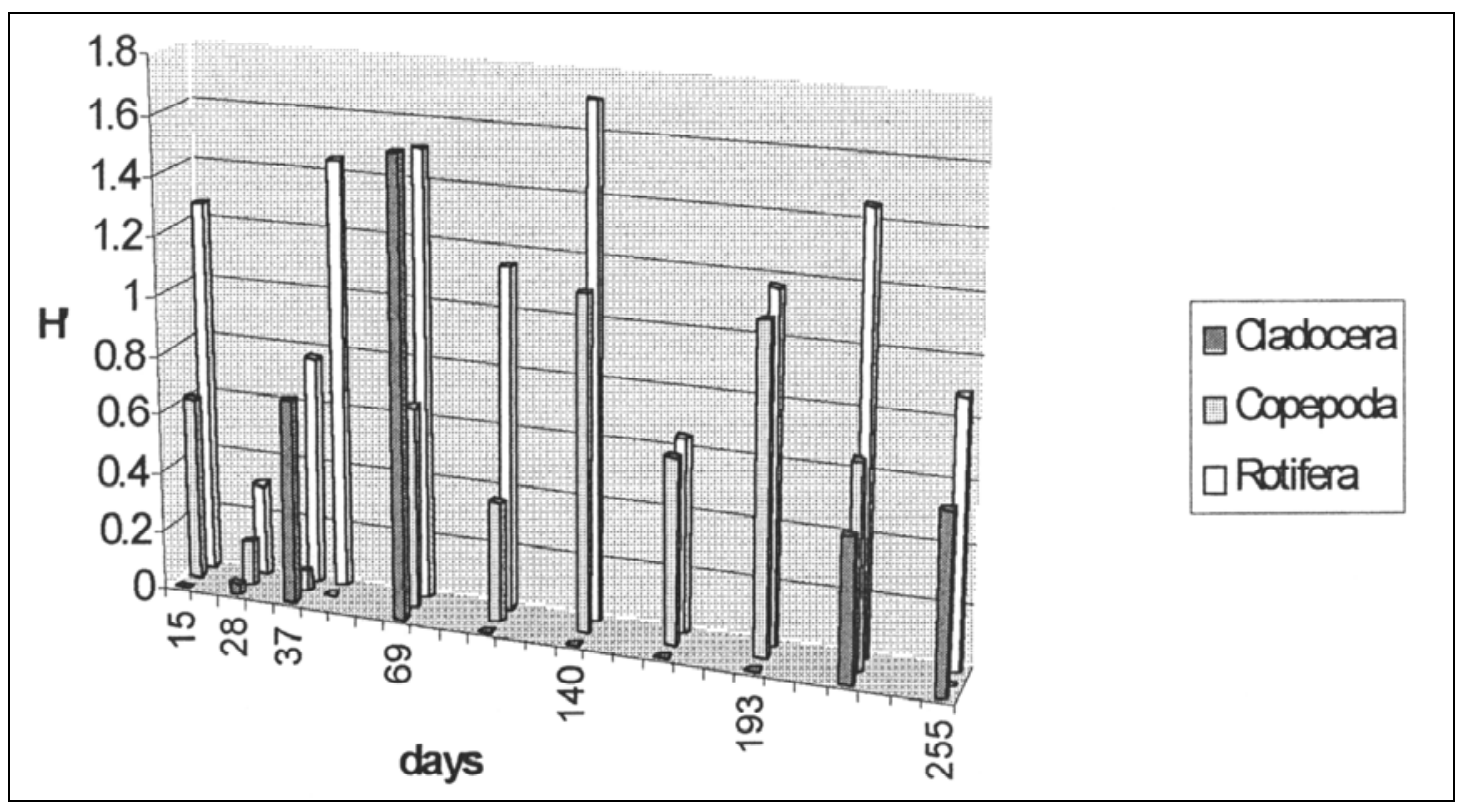

Figura 2. Diversity indices (H') along the study period.

be observed in Taperoá River was M. meridianus and Muscocyclops sp., both were observed on our first sample, 15 days after the beginning of the rain. M. meridianus attained its highest density on day 28 and then was only seen again on day 69 with very low densities (0.01 ind. $\left.\mathrm{L}^{-1}\right)$ while Muscocyclops sp. was only observed in the first sample. The next species to appear was M. brauni, on day 28. This species reached its highest density values on day 37 , with 35.8 ind. $\mathrm{L}^{-1}$. Afterwards it was only present in very low densities $\left(\approx 0.3\right.$ ind. $\left.\mathrm{L}^{-1}\right)$ on days 69 and 140 . The calanoide $N$. cearensis was observed first on day 37, with very low densities $\left(0.5\right.$ ind. $\left.\mathrm{L}^{-1}\right)$ and then again on day 170 with similar densities. The cyclopoid sp.3 was noted on day 43 with very low density values, 0.03 ind. $\mathrm{L}^{-1}$. This species was not found again. T. crassus was observed on day 69 , also with low densities $\left(0.4\right.$ ind. $\left.\mathrm{L}^{-1}\right)$, and was not found again either. A cyclopoid harpacticoid was observed on day 99, with 2.9 ind. $\mathrm{L}^{-1}$ and on day 193 with 0.5 ind. $\mathrm{L}^{-1}$. M. brasilianus and cyclopoid sp.1 were both found on day 140 with 0.8 ind. $\mathrm{L}^{-1}$. M. brasilianus was seen until the day 193 , but cyclopoid sp. 1 only was observed again on day 170. Both species achieved almost the same densities along the study period. The ecological succession observed for copepods was:
M. meridianus $=$ Muscocyclops sp.

M. brauni $\rightarrow N$. cearensis $\rightarrow$ cyclopoid sp.3 $\rightarrow$ T. crassus $\rightarrow$ Harpacticoida M. brasilianus = cyclopoid sp. 1 .

Similar to cladocerans, copepod species remained on the environment briefly, and then disappeared again.

Diversity index presented higher values on days 140 and 193 , with $\mathrm{H}^{\prime}=1.12$ and 1.10, respectively. Copepod values were only 0.00 on two sampling dates due to the presence of only one species. This group was always present during the study period.

Correlations were significantly negative between $M$. meridianus and alkalinity $(\mathrm{r}=-0.757, \mathrm{~N}=7, \mathrm{P}<0.05)$ and between nitrate and cyclopoid sp. 1 $(\mathrm{r}=-0.845, \mathrm{~N}=6, \mathrm{P}<0.05)$.

\section{Rotifera}

This was the group most best represented in the river, with 36 species and sub-species present: Anuaeropsis fissa, Asplanchna sieboldi, Brachionus angularis, $B$. angularis chelonis, $B$. angularis pseudodolabratus, B. bidentata, B. budapestinensis, B. calyciflorus, B. caudatus austrogenitus, B. havanaensis, B. patulus, B. urceolaris, B. urceolaris nilsoni, Colurela uncinata, Conochilus natans, Dipleuchnis propatula, 
F. longiseta, F. longiseta passa, F. longiseta saltitor, F. opoliensis, Hexarthra intermedia, Keratella americana, $K$. lenzi, $K$. procurva, K. tropica, Lecane hastata, L. leontina, L. luna, L. (Monostyla) brita, L. (M.) lunaris, Lepadella imbricata, Polyarthra dolichoptera, P. vulgaris, Testudinella patina, Trichocerca sp., and a not loricated form unidentified.

These species were generally present in one or two sampling dates, not to be observed again. The other species did not displayed a defined pattern being present throughout the study period.

Significant negative correlations were found between hardness and B. caudatus austrogenitus $(\mathrm{r}=-0.802$, $\mathrm{N}=7, \mathrm{P}<0.05)$ and positive ones were observed between ammonium and B. calyciflorus, B. urceolaris nilsoni, $B$. bidentata and $F$. longiseta passa all with $\mathrm{r}=0.694, \mathrm{~N}=7, \mathrm{P}<0.05$; alkalinity and P. vulgaris $(\mathrm{r}=0.690, \quad \mathrm{~N}=6, \quad \mathrm{P}<0.05)$; nitrate and $L$. imbricata, $D$. propagula, L. (M.) bulla, L. leontina and K. americana, all with $\mathrm{r}=0.767, \mathrm{~N}=6, \mathrm{P}<0.05$. Positive correlations were also found between chlorophyll $a$ values and $F$. longiseta $(\mathrm{r}=0.882, \mathrm{~N}=7, \mathrm{P}<0.01)$, B. urceolaris $(\mathrm{r}=0.876, \quad \mathrm{~N}=7, \quad \mathrm{P}<0.01)$, B. budapestinensis $\quad(\mathrm{r}=0.674, \quad \mathrm{~N}=7$, $\mathrm{P}<0.05), \quad$ C. natans $(\mathrm{r}=0.957, \quad \mathrm{~N}=7$, $\mathrm{P}<0.01), \quad$ L. luna $\quad(\mathrm{r}=0.789, \quad \mathrm{~N}=7$, $\mathrm{P}<0.05), F$. opoliensis $(\mathrm{r}=0.957, \mathrm{~N}=7$, $\mathrm{P}<0.01)$, B. angularis pseudodolabratus $(\mathrm{r}=0.957, \mathrm{~N}=7, \mathrm{P}<0.01), K$. procurva $(\mathrm{r}=0.957, \quad \mathrm{~N}=7, \quad \mathrm{P}<0.01)$, Trichocerca sp. $\quad(\mathrm{r}=0.730, \quad \mathrm{~N}=7, \quad \mathrm{P}<0.05)$, B. angularis chelonis $(\mathrm{r}=0.685, \mathrm{~N}=7$, $\mathrm{P}<0.05)$ and biomass and $F$. longiseta $(\mathrm{r}=0.881, \mathrm{~N}=7, \mathrm{P}<0.01)$, B. urceolaris $(\mathrm{r}=0.911, \quad \mathrm{~N}=7, \quad \mathrm{P}<0.01), \quad C$. natans $(\mathrm{r}=0.941, \quad \mathrm{~N}=7, \quad \mathrm{P}<0.01), \quad$ L. luna $(\mathrm{r}=0.757, \mathrm{~N}=7, \mathrm{P}<0.05), F$. opoliensis $(\mathrm{r}=0.941, \mathrm{~N}=7, \mathrm{P}<0.01), B$. angularis pseudodolabratus $\quad(\mathrm{r}=0.941, \quad \mathrm{~N}=7$, $\mathrm{P}<0.01), K$. procurva $(\mathrm{r}=0,941, \mathrm{~N}=7$, $\mathrm{P}<0.01)$ and Trichocerca sp. $(\mathrm{r}=0.693$, $\mathrm{N}=7, \mathrm{P}<0.05)$.

Significant negative correlations were found between hardness and B. caudatus austrogenitus $\quad(\mathrm{r}=-0.802$,
$\mathrm{N}=7, \mathrm{P}<0.05)$ and positive ones were observed between ammonium and B. calyciflorus, B. urceolaris nilsoni, $B$. bidentata and $F$. longiseta passa all with $\mathrm{r}=0.694, \mathrm{~N}=7, \mathrm{P}<0.05$; alkalinity and P. vulgaris $(\mathrm{r}=0.690, \quad \mathrm{~N}=6, \quad \mathrm{P}<0.05)$; nitrate and $L$. imbricata, D. propagula, L. (M.) bulla, L. leontina and K. americana, all with $\mathrm{r}=0.767, \mathrm{~N}=6, \mathrm{P}<0.05$. Positive correlations were also found between chlorophyll $a$ values and $F$. longiseta $(\mathrm{r}=0.882, \mathrm{~N}=7, \mathrm{P}<0.01)$, B. urceolaris $(\mathrm{r}=0.876, \quad \mathrm{~N}=7, \quad \mathrm{P}<0.01)$, B. budapestinensis $\quad(\mathrm{r}=0.674, \quad \mathrm{~N}=7$, $\mathrm{P}<0.05), \quad$ C. natans $(\mathrm{r}=0.957, \quad \mathrm{~N}=7$, $\mathrm{P}<0.01), \quad$ L. luna $\quad(\mathrm{r}=0.789, \quad \mathrm{~N}=7$, $\mathrm{P}<0.05), F$. opoliensis $(\mathrm{r}=0.957, \mathrm{~N}=7$, $\mathrm{P}<0.01$ ), B. angularis pseudodolabratus $(\mathrm{r}=0.957, \mathrm{~N}=7, \mathrm{P}<0.01), K$. procurva $(\mathrm{r}=0.957, \quad \mathrm{~N}=7, \quad \mathrm{P}<0.01)$, Trichocerca sp. $\quad(\mathrm{r}=0.730, \quad \mathrm{~N}=7, \quad \mathrm{P}<0.05)$, B. angularis chelonis $(\mathrm{r}=0.685, \mathrm{~N}=7$, $\mathrm{P}<0.05)$ and biomass and $F$. longiseta $(\mathrm{r}=0.881, \mathrm{~N}=7, \mathrm{P}<0.01)$, B. urceolaris $(\mathrm{r}=0.911, \quad \mathrm{~N}=7, \quad \mathrm{P}<0.01), \quad C . \quad$ natans $(\mathrm{r}=0.941, \quad \mathrm{~N}=7, \quad \mathrm{P}<0.01), \quad$ L. luna $(\mathrm{r}=0.757, \mathrm{~N}=7, \mathrm{P}<0.05), F$. opoliensis $(\mathrm{r}=0.941, \mathrm{~N}=7, \mathrm{P}<0.01)$, B. angularis pseudodolabratus $\quad(\mathrm{r}=0.941, \quad \mathrm{~N}=7$, $\mathrm{P}<0.01)$, K. procurva $(\mathrm{r}=0,941, \mathrm{~N}=7$, $\mathrm{P}<0.01)$ and Trichocerca sp. $(\mathrm{r}=0.693$, $\mathrm{N}=7, \mathrm{P}<0.05$ ).

The peak of existent species occurred between the days 37 and 140 (halfway the study length) with 11 to 14 species present. The higher number of species (14) was found on day 99. Nevertheless the highest diversity index was found on day 140. This was due to the eveness index that was lower on day 99. The lowest number of species, (4) was found on day 193 .

The following rotifers succession was observed:

B. ca1ycflorus / B. bidentata / B. urceolaris nilsoni / F. longiseta passa $\rightarrow$ A. fissa / C. natans $\rightarrow K$. lenzi $\rightarrow K$. procurva / $B$. angularis pseudodolabratus

L. imbricata / L. leontina / L. (M.) bulla / $D$. propatula $\rightarrow T$. patina / L. lunaris / F. longiseta saltitor $\rightarrow$ B. havanaensis P. vulgaris. 


\section{Discussion}

Succession of species occur when the environment undergoes changes due to chemical or physical interference, but succession can also occur in rotifer species in chemically stable environments, due to competition with cladocerans and predation (Urabe, 1992). Almost all species present in this work showed short life spans, being substituted one for another along the period the river had water. This was probably due to changes in chemical environment and resources, as well specific interference. In a specific time the habitat is suitable for some species but not to others, and when the environment changes becames suitable for the others. This allows, nevertheless their rapid succession in the environment, for the existence of a great number of species along a hydrological cycle. $\mathrm{Hu}$ and Tessier (1995) suggested that the emergence of Daphnia galeata mendotae as a superior competitor in late summer was related to a seasonal change in resource composition, at least when planktivory is low.

In a succession study of cladocerans in a ricefield in ltaly, it was observed that an increase in Chydoridae was associated with the growth and decomposition of a large biomass of weeds and microalgae during the summer (Ferrari et al., 1991). In our work Chydoridae species also increased on the second half period of the study when the river became eutrophic. Trophic conditions changed quickly from oligotrophic to hypereutrophic in almost 9 months.

Pearson's correlations observed between chemical factors and species, on this work, must be confirmed in other similar environments to conclude that those species are really sensitive to those factors. Chlorophyll $a$ and biomass of phytoplankton were the main correlated factors for the greater number of rotifer species (10 and 8 respectively), showing that resources are more important in structuring the community than chemical factors. Nevertheless nitrate and ammonium values were correlated with 5 and 4 species respectively.

Diversity indices were higher for cladocerans on day 69 and for copepods and rotifers on day 140, although on day
193 copepods have the same H' value. On day 69, 6 cladoceran species were present. It seems that the environment became suitable for cladocerans earlier than for rotifers and copepods, although before day 69 only one or two species could be found in the water. Diversity indices, in Rotatoria, in two small rivers in Latvia, were related with trophic state and erosion in the river basin (Cimdins and Klavins, 1998). In our work rotifer diversity oscillated along the 9 months the river remained with water in the pond, showing 2 peaks: the first on day 140 and the second on day 211 .

A high number of species was observed during the course of the study, 36 rotifers, 9 cladocerans and 9 copepod. An ecological succession was observed especially on the first 99 days. Generally the time that the species remaining in the pond formed on the river was very short. The species ecloded from diapausing stages, reproduced, produced new diapausing stages and disappeared again. The present work shows that some species, specially rotifers (e.g. C. natans) on early samplings, can disappear in less than 30 days, so the sampling period for these must be lower than a month.

\section{References}

Arbaciauskas, K. Life-history traits of exephippial and parthenogenetically derived daphnids: indicators of different life-history strategies. Arch. Hydrobiol. Spec. Issues Advanc. Limnol., v. 52, p. 339-358, 1998.

Barbosa, J. E. L.; Medeiros, E. S. F.; Brasil, J.; Cordeiro, R. S.; Crispim, M. C. B.; Silva, G. H. G. Aquatic systems in semi-arid Brazil: limnology and management. Acta Limnol. Bras., v. 24, p. 103-118, 2012.

Chatterjee, K.; Gopal, B. Experimental study of emergence of zooplankton in temporary waterbodies in relation to dry periods. Verh. Internat. Verein. Limnol., v. 26, p. 1309-1315, 1998.

Cimdins, P.; Klavins, M. Water quality and species diversity of inland waters in Latvia. Verh. Internat. Verein. Limnol., v. 26, p. 1209-1211, 1998.

Crispim, M. C.; Paz, R. J.; Watanabe, T. Comparison of different Moina minuta populations dynamics ecloded from resting eggs in a semi-arid region in Brazil. Brazilian Journal of Ecology, v. 5/6, p. 33-38, 2003. 
Crispim, M. C.; Watanabe, T. What can dry reservoir sediments in a semi-arid region in Brazil tell us about cladocera? Hydrobiologia, v. 442, p. 101-105, 2001.

Eaton, A. D.; Clesceri, L. S.; Greenberg, A. E. Standard methods for examination of water and wastewater. 19. ed. Washington: APHA, AWA, WEF, 1995.

Fernandes, A. P. C.; Braghin, L. S. M.; Nedli, J.; Palazzo, F.; Lansac-Tôha, F. A.; Bonecker, C. C. Passive zooplankton community in different environments of a neotropical floodplain. Acta Scientiarum Biological Sciences, v. 34, p. 413-418, 2012.

Ferrari, I.; Bachiorri, A.; Margaritora, F. G.; Rossi, V. Succession of cladocerans in a Northern Italian ricefield. Hydrobiologia, v. 225, p. 309-318, 1991.

Fryer, G. Diapause, a potent force in the evolution of freshwater crustaceans. Hydrobiologia, v. 320, p. 1-14, 1996.

Gilbert, J. J. Structure, development and induction of a new diapause stage in rotifers. Freshwater Biology, v. 34, p. 263-270, 1995.

Golterman, H. L.; Clymo, R. S.; Ohnstad, M. A. M. Methods for physical and chemical analysis of fresh water. 2. ed. Oxford: Blackwell Scientific Publication, 1978.

Hairston, N. G.; Cáceres, C. E. Distribution of crustacean diapause: micro- and macroevolutionary pattern and process. Hydrobiologia, v. 320, p. 27-44, 1996.

Hu, S. S.; Tessier, A. J. Seasonal succession and the strength of intra- and interspecific competition in a Daphnia assemblage. Ecology, v. 76, p. 2278-2294, 1995.

King, C. E.; Snell, T. W. Density-dependent sexual reproduction in natural populations of the rotifer Asplanchna girodi. Hydrobiologia, v. 73, p. 149-152, 1980.
Odum, E. P. Fundamentos de Ecologia. 4. ed. Lisboa: Fundação Calouste Gulbenkian, 1988.

Palazzo, F.; Bonecker, C. C.; Nagae, M. Y. Zooplankton dormancy forms in two environments of the Upper Paraná River floodplain (Brazil). Acta Limnol. Bras., v. 20, p. 55-62, 2008.

Panarelli, E. A; Casanova, S. M. C.; Henry, R. The role of resting eggs in the recovery of zooplankton community in a marginal lake of the Paranapanema River (São Paulo, Brazil), after a long drought period. Acta Limnol. Bras., v. 20, p. 75-90, 2008.

Ponce-Palofox, J. T.; Aredondo-Figueroa, J. L. An analysis of factors governing metabolism of temporary tropical freshwater pond ecosystem. Verh. Intemat. Verein. Limnol., v. 26, p. 1571-1574, 1998.

Rodier, J. L'analyse de l'eau: Eaux natureile, eaux résidualle, eaux de mer. 5. ed. Paris: Dunod, 1975. v. 1.

Rossi, V.; Gandolfi, A.; Menozzi, P. Egg diapause and clonal structure in parthenogenetic populations of Heterocpris incongruens (Ostracoda). Hydrobiologia, v. 320, p. 45-54, 1996.

Serrano, L.; Toja, J. Interannual variability in the zooplankton community of a shalow temporary pond. Verh. Internat. Verein. Limnol., v. 26, p. 1575-1581, 1998.

Urabe, J. Midsummer succession of rotifer plankton in a shallow eutrophic pond. J. Plankton Res, v. 14, p. 851-866, 1992.

Vandekerkhove, J.; Declerck, S.; Vanhove, M.; Brendonck, L.; Jeppesen, E.; Conde Porcuna, J. M.; De Meester, L. Use of ephippial morphology to assess richness of anomopods: potentials and pitfalls. J. Limnol., v. 63, Suppl. 1, p. 75-84, 2004.

License information: This is an open-access article distributed under the terms of the Creative Commons Attribution License, which permits unrestricted use, distribution, and reproduction in any medium, provided the original work is properly cited. 